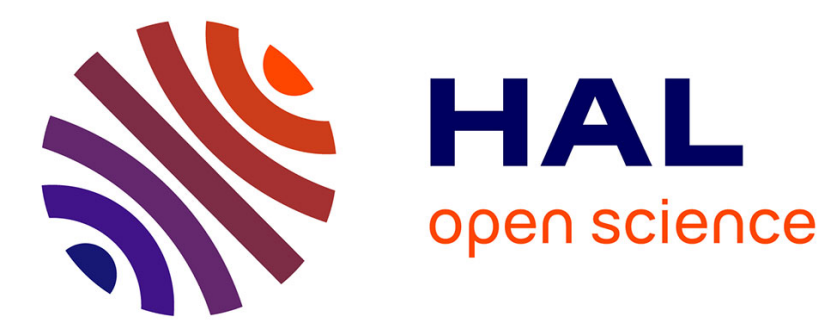

\title{
Perfectionism in Practice: Shusterman's Place in Recent Pragmatism
}

\author{
Mathias Girel
}

\section{To cite this version:}

Mathias Girel. Perfectionism in Practice: Shusterman's Place in Recent Pragmatism. Contemporary Pragmatism, 2015, 12 (1), pp.156-179. 10.1163/18758185-01201009 . hal-01388796

\section{HAL Id: hal-01388796 https://hal.science/hal-01388796}

Submitted on 2 Nov 2016

HAL is a multi-disciplinary open access archive for the deposit and dissemination of scientific research documents, whether they are published or not. The documents may come from teaching and research institutions in France or abroad, or from public or private research centers.
L'archive ouverte pluridisciplinaire HAL, est destinée au dépôt et à la diffusion de documents scientifiques de niveau recherche, publiés ou non, émanant des établissements d'enseignement et de recherche français ou étrangers, des laboratoires publics ou privés. 


\title{
Perfectionism in Practice: Shusterman's place in Recent Pragmatism
}

\author{
Mathias GIREL \\ Associate Professor, Ecole normale supérieure, 45, rue d'Ulm, 75231 Paris \\ cedex 05, Lab: "République des savoirs" (ENS/Collège de France/CNRS), \\ USR3608 \\ mathias.girel@ens.fr \\ +33144323011.
}

\begin{abstract}
Building on recent texts, I give a characterization of Richard Shusterman's specific variant of pragmatism, understood as a melioristic or perfectionist pragmatism, where ethical and political dimensions are deeply intertwined with the epistemological one. To do so, I focus on what seems to be Shusterman's latest contribution to his interrupted dialogue with Richard Rorty in Thinking through the Body (ch. 8, "Pragmatism and Cultural Politics: From Textualism to Somaesthetics").
\end{abstract}

Thinking Through the Body (hereafter: TTTB) is an important milestone in the history of post-2000 pragmatism, as Richard Shusterman's distinctive take on this philosophical tradition is reaching its full development, after fifteen years at least of maturation of his own disciplinary proposal, Somaesthetics. William James notoriously compared pragmatism "as a method" with a corridor, leading to a variety of different rooms, one room where someone is eager to destroy metaphysics, another where someone is experimenting, another again where someone is praying1. The implication was that other substantial commitments, radical empiricism for himself, tricategorial realism for Peirce, Humanism for Schiller, delineated as many distinct philosophies, pragmatisms in the plural, in contrast with pragmatism as a method or inspiration. I shall try and give a rough characterization of Richard Shusterman's special room ${ }^{2}$ in this Pragmatist Hotel, and to do so, I shall focus on what seems to be Shusterman's latest answer in his interrupted dialogue with Richard Rorty (TTTB, ch. 8, Pragmatism and Cultural Politics: From Textualism to Somaesthetics)3. A bit of context is needed before presenting my claim. Since the publication of Richard Rorty's Philosophy and the mirror of nature 4 , and more importantly, his Consequences of Pragmatism5, some thirty years ago, an intense "revival" 6 of Pragmatism has occurred in philosophy and the human sciences, in large part 
under Rorty's initial influence. The very term of revival could be disputed since what took place then, after the "linguistic" turn7 in philosophy, was certainly very different from the original phenomenon 8 , but there is at least one common point between the two periods: the revival soon turned into a dispute over the right pragmatist direction as vivid as the first 1900-1910 debate over Pragmatism. For nearly a decade, the whole philosophical world had to witness, and sometimes engage in, a strange gigantomachy between Rorty and Putnam, between what came to be seen as the "two" pragmatisms9, one allegedly inclined towards science and realism, Putnam's own strain ${ }^{10}$, the other being more difficult to characterize. Was the "other" pragmatism more "literary", more grounded in a kind of anthropological naturalism, more pluralist, antirealist, relativist?

This indecision is a sure sign that this dualist characterization was more akin to a political strategy designed to exclude whatever did not fit the first description than a "wrapper-definition"11 of the field. Rorty was articulating an original kind of linguistic pragmatism, where his notion of "vocabulary" played a prominent role ${ }^{12}$, a project taken further in the 1990 s by one of his most distinguished students, Robert Brandom ${ }^{13}$. However, it can be argued that readers were sometimes too impressed by the destructive side of Rorty's criticisms of remnants of positivism to pay attention to the positive resources Pragmatism was offering. In his anti-essentialist crusade, Rorty enrolled not only thinkers such as James and Dewey, but also Quine, Sellars and Davidson, who did not identify themselves as pragmatists 14 but "who successfully, and rightly, blur[red] the positivist distinctions between the semantic and the pragmatic, the analytic and the synthetic, the linguistic and the empirical, theory and observation. 15 " Whether or not this captures an essential pragmatist insight, one thing is sure: one of the sundry effects of this loud controversy has been to obscure, for some time, other innovative and challenging uses of pragmatism in semantics, sociology, economics, literary theory and the philosophy of art ${ }^{16}$.

Richard Shusterman's trajectory is in some important respects representative of a powerful and significant trend in this revival, and he contributed himself to it in an original manner, since the late 1980 s. If this point is not always given its due in recent accounts of pragmatism, this is because these often stick to the conceived boundaries of academic disciplines ${ }^{17}$ - at odds with the spirit of pragmatism itself. In this paper, I'll focus on Shusterman's specific version of pragmatism as a melioristic or perfectionist pragmatism, where ethical and political dimensions are deeply intertwined with the epistemological one. My goal, at this stage, is more descriptive than critical: I shall try to show, here how these dimensions are articulated, and Shusterman's debate with Rorty will be crucial to do this.

Several tasks are in order to make this articulation explicit. In chapter 8 of TTTB Shusterman "provides a detailed analysis of the major differences 
between Rorty's and [his] versions of pragmatism" and situates "somaesthetics in the broader, contestatory field of contemporary pragmatism"(TTTB, 167), but, oddly enough, there are not so many independent accounts of Shusterman's own pragmatism. So in section 1 I give my own account of his views, articulating what I take to be two strands: Shusterman's Pragmatism and what could be called Shustermanian Pragmatism.

Section 2 deals then with a major bone of contention between Rorty and Shusterman: Experience is not an "epistemological" concept but the locus of enhancement; it is a key category for meliorism.

This point is further expanded in section 3, which draws on materials taken in recent texts and addresses Shusterman's recent characterizations of Pragmatism. I'll show that the melioristic aspect "controls" the other dimensions of his account of Pragmatism.

I shall thus be better equipped to understand why Shusterman sees in Rorty's final writings on pragmatism (in Philosophy as Cultural Politics) a move that should have led to a more complete agreement between them (section 4).

\section{Shusterman's Pragmatism(s)}

Three points should be made, in order to highlight both Shusterman's representative status and his originality in the Pragmatist revival.

1) One of Rorty's points, both in 1979 and 1982, was that the history of the analytic movement in the United States had been "marked by a gradual 'pragmaticization' of the original tenets of logical positivism"18 and, as a consequence, of analytic philosophy itself. Even the late works of Carnap and Reichenbach seemed to illustrate this. The diagnosis applies quite well to Rorty (who started as a strict analytic philosopher), to Putnam, and also describes quite well Richard Shusterman's evolution in the 1980s, especially after he joined Temple University, coming from Israel's University of the Negev after his doctoral studies at Oxford. His academic background - first, inspired by the nominalist ontology of Nelson Goodman, then by British-style ordinary language philosophy when at Oxford - was in analytic philosophy and analytic aesthetics to which he devoted his thesis and his first series of papers ${ }^{19}$. It would be possible to point two stages in his own "pragmaticization":

(a) In the first stage he maintained what seems to be already a pragmatist account of interpretation and evaluation. The Object of Literary Criticism ${ }^{20}$ adapted from his $\mathrm{PhD}$ thesis - certainly belongs to this period; and important aspects of his book on Eliot have a definite pragmatic bent ${ }^{21}$, consonant with the new influence of Rorty's pragmatism and, perhaps, something of Joseph Margolis's who was Shusterman's colleague at Temple University; (b) the second stage is where Shusterman offers a vivid and explicit reinterpretation of the classical pragmatists (Dewey being the first one he considers) and also develops a number of inquiries that put the somatic dimension of experience in particular focus. 
Both of these projects are enlisted and pursued through a meliorist perspective. It is in this period that he articulates a full-fledged "Shustermanian" Pragmatism, his conversion happening, in some of the sundry narratives he offers, during the spring or summer of $1988 .{ }^{22}$ In perfectionist terms, one could describe this as a conversion to his own pragmatism, or, to his own singular voice in the pragmatist current. The first period is certainly crucial to assess the scope of his overall pragmatist stance, the second one is decisive, as far as the personal transformation or distinctive contribution he introduced to the history of pragmatism and its classical corpus. Let's characterize the two stages a bit more precisely, just to show that their logics are different.

2) Many important thinkers have combined analytic method and a set of pragmatist positions: this is still the case of Hilary Putnam now in 2015. So it does not always make sense to try to determine when someone has abandoned analytic philosophy to become a pragmatist. Still, there are times when the basic assumptions of a field stand in the way of inquiry and when they have to be revised. From that standpoint, the move out of orthodox analytic philosophy was definitely well on its way when Shusterman edited Analytics Aesthetics 23 . His foreword articulated a strong charge against "analytic purism" in criticical theory and claimed that the mistaken idea that "there is or must be one essential or proper interpretive logic (whether objectivist, relativist, non-cognitivist etc.) which underlies all good criticism" was "perhaps a vestige of essentialism that analytics aesthetics had great trouble shedding" 24 . The very idea that there was such a logic was crucial indeed for standard analytic aesthetics, whereas pragmatism, with its native pluralism and anti-essentialism, was a strong antidote to this line of thought. Further, the idea that philosophy is a kind of meliorative criticism, a "criticism of criticisms" 25 (as Dewey would have it) is already articulated in that book. Contrariwise to the analytic "acquiescence" 26 culminating in the idea that philosophy should only state what works of art are rather than what they should or could be - philosophy (here in terms of what could be the best direction for analytic aesthetics as guided by pragmatist lights), should (in Shusterman's words) "take a more activist and interventionist role in the contest over nature of art and art criticism rather than simply clarify or logically explicate, with implicit acquiescence, what the prominent critics see fit to do $27 . "$

This is already the germ of Pragmatist Aesthetics, but one can also read these two quotes from Analytic Aesthetics as summing up Shusterman's initial work on critical theory since the early eighties: first, the idea that there is a plurality of logics for interpretation and evaluation; second, that providing a theory of criticism does not make sense if one does not highlight and build on actual critical practice (such as Eliot's, for example); third, that there is an important historicist and contextual dimension to interpretation and evaluation. Shusterman's emphasis here on this background initially shows the influence of Austin and Wittgenstein but later is joined by Dewey, Bourdieu and Foucault. Since Shusterman admits that he still shares these beliefs, some thirty 
years after his first book, ${ }^{28}$ I propose to call this position "Shusterman's general pragmatism". It is the backbone of a methodological position, where pragmatism (used in a very general sense or sometimes simply just presupposed) is a via media between the strictures of analytic philosophy and the dissolving effects of deconstructionism.

3) The explicit recourse to Dewey (as contrasted with an implicit endorsement of pragmatist strategy), is fully present in what still reads like a little manifesto Shusterman wrote in 1989, where Dewey's merits, his somatic naturalism in particular as well as the central role he assigns to art, are emphasized:

Since Dewey's aesthetics offers crucial insights lacking in the analytic tradition and obtainable from Continental theory only at the costly price of conceptual obfuscation, rebarbative jargon, and irrelevant theoretical baggage, it represents the best point of departure for new aesthetic thinking in Anglo-American philosophy. 29

Shusterman has provided several accounts of his reorientation during the $19803^{\circ}$, but, with the benefit of hindsight, we can say that his distinctive "move" in the late eighties was triple, and each dimension was a transformation of the given state of pragmatism: $(a)$ he resolutely put Dewey in center stage (even Rorty was perhaps less decisive in this at that time). (b) He made a daring double wager: first, that Art as Experience was worth reviving (contrary to the nearly unanimous bent of analytic aesthetics and even of influential pragmatists, such as Rorty); secondly that it captured something essential in Dewey's general meliorative vision. The transformation Shusterman here imposed has been much more than a "revival" of Dewey's pragmatist aesthetics, but rather its first real life. Art as experience was certainly read in some circles before Shusterman's book but in no comparable extent to its reception after his transformative rereading. (c) His final wager was that Dewey's aesthetics had to be defended against the letter of Dewey's texts themselves: Dewey's latent organicism had to be corrected. Moreover, the substantive treatment of aesthetic experience in popular art and everyday culture (whose detailed elaboration was surprisingly absent from Dewey's Art as experience) received pride of place in Shusterman's Pragmatist Aesthetics. Dewey had issued a kind of "promissory note"in Chapter 1 of Art as Experience: "The arts which today have most vitality for the average person are things he does not take to be arts: for instance, the movie, jazzed music, the comic strip, and, too frequently, newspaper accounts of love nests, murders, and exploits of bandits31." Alas, these materials were in no way elaborated in Art as Experience. Jazz, films, popular literature were not discussed and what comes closest to contemporary art is actually neo-impressionism. Rap and country music, some of the examples analyzed by Shusterman in Pragmatist Aesthetics and Performing Live, were just first steps in a re-appropriation of everyday culture, that is to say in driving both Dewey's democratic and aesthetic projects 
home. This move could be dubbed "Shustermanian Pragmatism", by distinction with the first trend. In that second phase of the "conversion", the notion of experience has been very instrumental, and we shall now see why it is an open question whether Shusterman's position is better depicted as a kind of "enhanced empiricism" or as a pragmatism.

\section{Enhanced Experience}

\section{Experience [...] remains the vital heart of philosophy32.}

To understand the background of Chapter 8 and of the tension between the two philosophers, it is worth remarking that Rorty is an important reference in Shusterman's early texts, but that the latter's appropriation of Dewey involves the very point where he himself differs from Rorty. To put it in a nutshell, Shusterman's reading of the pragmatist movement consists in holding firmly to the "somatic and non-propositional dimension of experience", and thus retaining the very idea of experience that Rorty wants so much to dismiss as the ultimate refuge of the "myth of the given". This opposition plays an important role in the recapitulation Shusterman provides of the differences between him and Rorty (TTTB, Ch. 8, III; see also p. 171). As Shusterman puts it elsewhere:

I differ not only from Rorty but from all the other pragmatists I mention by insisting on the value of the non-linguistic dimension of experience (the other philosophers tend to equate experience with linguistic experience and Rorty rejects the notion of experience altogether) and on the importance of attention to a bodily dimension of philosophy, which I partly pursue through the notion of philosophy as a way of life.33

The two philosophers thus meet on the background of a major difference, as much from Shusterman's standpoint as from Rorty's, including what the latter had to say about the somaesthetic project34. It is fair to say that, more than the 1980 s notion of the "two" pragmatisms, the question of experience draws a sharp divide in the pragmatist field, whose extremes are occupied right now by Shusterman, on the one hand, Brandom and some neohegelian idealists, on the other hand.

Dewey and James, from this standpoint, are strategic authors for the position endorsed by Shusterman in the pragmatist renascence, whether one has in mind Dewey's 1905 "immediate empiricism", the quintessence of which is provided by the more mature Art as experience (1934), or what James called his "radical" empiricism, as articulated in a series of papers in 1904-1905. James is interesting (and has been increasingly present in Shusterman's writings) because one of the major problems of radical empiricism is the status of "pure" experience, experience before or beneath the state where it is "shot through with adjectives and nouns and prepositions and conjunctions." 35 Here, also, a certain 
amount of non-propositional experience is at stake: "Its purity is only a relative term, meaning the proportional amount of unverbalized sensation which it still embodies." 36 This realm of experience is rooted in somatic activity, something strikingly depicted in James's "The Experience of Activity", an important text from Shusterman's standpoint: "The body is the storm centre, the origin of coordinates, the constant place of stress in all that experience-train. Everything circles round it and is felt from its point of view."37

Thus, on one side, there is a lineage of pragmatism where some form of empiricism is the necessary complement of the pragmatist "method" or "attitude", and Richard Shusterman can easily stand as a paradigmatic representative of this current (an "exemplar" as Nietzsche would say). On the other hand, we have a lineage where the most famous representative now is Robert Brandom. This second strand, sometimes inspired by Sellars, claims that the linguistic turn has induced an irreversible change of vocabulary in philosophy and that there is no way to redeem the "pre-turn" notion of experience.

Brandom is an avowed anti-empiricist pragmatist. He even claims that the word "experience" is not used even once in a technical sense in his voluminous Making it Explicit38. Or, in Brandom's words: “Experience' is not one of my words39."In his eyes, experience has all the characteristics of what Sellars calls the given, that is to say of a self-justifying episode that would confer epistemic authority to other epistemic episodes without having to obey the basic minimal rule to be admitted in the "space of reasons": being able to enter "the game of giving and asking for reasons". Experience, in this context, is a mongrel concept, a queer intermediary "between perceptible facts and reports of them that are non-inferentially elicited by the exercise of reliable differential responsive dispositions.40" Brandom is quite willing to admit that we have both levels, that we perceive and that we are able to report about these perceptions, but not that experience itself would be the common ground to both of these registers. In that, Brandom is Rortyan and Sellarsian, and he is Rortyan on the very point where Rorty converges with Sellars on the criticism of the Myth of the Given.

Against Rorty, Shusterman argues in TTTB, as he did in "Beneath Interpretation," that "interpretation" does not come first but presupposes "understanding" which is "more basic or prior than interpretation; it is what interpretation relies or builds on, even if such basic understandings were at some point shaped by earlier interpretations, which relied on still other understandings", p. 174). Understanding of this kind can be non-linguistic, as in the intentional gestures or movements "of a dancer, lover, or ballplayer"(Ibid.), while being cultural through and through. As Shusterman explains:

These nonlinguistic understandings are not metaphysically primordial, purely physical "raw feels" that exist beyond the world of culture and thus inform us of the absolute nature of reality. Instead (like the rest of our 
experience), they are deeply shaped by culture and history, as are even the size and shape of our bodies (which obviously vary in terms of the diet and exercise we take). Rorty is therefore wrong to conclude that rejecting foundationalism entails rejecting the notion of nonlinguistic understanding. (TTTB, 175)

Another line of disagreement might be worth pursuing. Shusterman is not only an empiricist. He also affirms, as is evident throughout TTTB, a somatic naturalism as central to the particular kind of empiricism he endorses. This position is characteristic of his distinctive room or suite in the big pragmatist hotel and constitutes another point of disagreement with Brandom-style pragmatism. Brandom is at odds with this naturalism, endorsed by most of the classical pragmatists, which he dubs "assimilationism":

What one misses most in the pragmatists at any rate, what most separates them from us is that they do not (Peirce aside) share the distinctively twentieth century philosophical concern with language, and with the discontinuities with nature that it establishes and enforces. [...] This is partly because of the pragmatists' assimilationism about the conceptual: their emphasizing continuities between concept users and organic nature. [...] I [...] take it that the philosophical way forward from the ideas of the American pragmatists must be a linguistic pragmatism, allied with the later Wittgenstein and the Heidegger of Division One of Being and Time.41

Brandom dismisses exactly what will be of interest to the readers of the first chapter of Art as Experience, the very possibility of continuity between forms of life, which allows Dewey to open his book with the "Live Creature".

These are two different fronts, but let's assume, for the sake of the argument that the main disagreement lies with experience. The most telling reply to this charge by Shusterman is already in "Dewey and Experience: Foundation or Reconstruction" (1994)42, a very substantive text for his pragmatist position and one of my favorites of his earlier texts, where Rorty's dismissal of that very notion of experience, very similar to that of Brandom, is explicitly faced. It is possible indeed to make room for non-discursive and immediate experience without succumbing to the foundationalist fallacy: the goal of philosophy is not to provide foundations, it is transformative, it is to enhance experience, and that is a perspective even Rortyans could and should admit.

Philosophy should be transformational instead of foundational. Rather than a metascience for grounding our current cognitive and cultural activities, it should be cultural criticism that aims to reconstruct our practices 
and institutions so as to improve the quality of our lives. Improved experience, not originary truth, is the ultimate philosophical goal and criterion. 43

Rorty and Brandom's reproaches would thus be based on a mistaken idea of philosophy, confining its work to epistemology. Experience, for Shusterman, is not the non-discursive foundation of epistemological discourse, it is the locus of enhancement: "Dewey's prime purpose was the aesthetic and practical one of improving experience by making it the focus of our inquiry, of enriching and harmonizing our experience, for example, by affirming and enhancing the continuity between soma and psyche, between nondiscursive experience and conscious thought." 44 If Epistemology has to dismiss the spectator theory of knowledge, as James and Dewey claimed, empiricism also has to dismiss a too narrow and passive version of its central concept, Experience45. All great empiricists since James have been at war against some facets of classical empiricism; James against the assumption that our ideas or sensations should be determinate in all their aspects and that we could experience only terms and not their relations, Shusterman against the idea that experience - somatic experience - was only the correlative of cognition, and an outdated vision of cognition for that matter. Somatic disciplines contribute to this "improvement" of experience; and he shows us in the sundry chapters of TTTB many of the major avenues of this improvement.

How to gain control of one's experience, how to find oneself in that process, how to look after one's "unattained but attainable self" are the basic problems of perfectionism, and Shusterman's notion of experience leads straight to this series of problems.

Before we take them up, one last remark about experience seen from this standpoint. Shusterman sometimes refers to Bataille and Foucault and their idea of "limit-experiences". In the same way that Dewey shows us (in chapter 3 of Art as experience) that we can "have" an (aesthetic) experience, i.e. that we can so to say "experience experience" in its singularity and unity instead of also "knowing" it or having an abstract theory about it, Shusterman notes that some experiences give us a sense of the limitations of our experience. There is the familiar, fundamental Kantian problem of the possibility of experience and the limits of knowledge, but it can turn into a practical one.

The value of these limit-experiences lies not simply in their experiential intensity that seems related to the intense sublimities of aesthetic experience, but especially in their power to transform us by showing us the limits of our conventional experience and subjectivity and by introducing us to something fascinatingly powerful beyond those limits, an "au delà" of what we are and know. 46 
Shusterman reminds us that some of these limit-experiences can impair our future ability to experience. But there are other uncanny experiences, which can also provide, with lesser risks, this kind of “decentering”. Shusterman's own artistic experiences, notably as L'homme en Or ("The Man in Gold") in his collaborative work with the Parisian artist Yann Toma series (in their genre Somaflux which derives from Toma's Radiant Flux series), exemplify this testing of the "limits of our conventional experience," where Shusterman (clothed in a skintight gold body stocking) explores a variety of urban and natural contexts responding to the physical and social energies therein. 47

\section{Shusterman's Ten Commandments}

We are now better equipped to address Shusterman's recent views on pragmatism, which play a key role in his latest discussion of Rorty. I shall use a fairly recent paper, "What Pragmatism means to me" 48 , not included in TTTB, where Shusterman provides a survey of his own use of pragmatism in ten principles, as a kind of epitome of what he shares with the pragmatist tradition, and I shall read it as making the pragmatist background of TTTB explicit. An historian of ideas would certainly be interested in comparing Shusterman's principles with numerous earlier attempts at defining pragmatism, a long vexed question indeed, at least since Lovejoy's famous 1908 paper on the "thirteen pragmatisms" 49 , but I'll focus here on the special "twist" Shusterman gives to this tradition.

For that purpose, it might be worth mentioning two other academic attempts at definition. They might be more interesting than approaches coming from the main contemporary pragmatists because they seem, more clearly than others perhaps, to illustrate the two main stances towards Pragmatism. Philip Wiener, for example50, offered five features that seemed to him essential to classical pragmatism (which does not mean of course that all pragmatists subscribe to all of them): (1) a pluralistic empiricism, (2) a temporalist account of reality and knowledge, (3) a contextualist account of reality, (4) a probabilist view of physical and social laws, (5) a democratic and secular individualism. The new image of the world emerging in the 1860s, in the wake of Darwin's Origin of species 51 , the rise of probabilistic and relational thinking and an approach to language that was wary of ontological fictions certainly informed this philosophical sensibility and are certainly still part of today's pragmatist philosophical picture.

Wiener's criteria nevertheless don't say much about pragmatist epistemology and the pragmatic method, an aspect to which Thayer, in his classical account of pragmatism, was more responsive when he suggested that pragmatism was ( $\left.1^{\prime}\right)$ a maxim in philosophy and science for explicating the meanings of certain concepts (let's say it's a methodological and semantical rule), (2') a theory of knowledge and reality that articulates a naturalist approach to mind and thought, claiming that mind is shaped by our various interests and purposes, that thought is better judged by consequences than by origins (let's say it's a teleological approach to mind) (3') a view of theory where "theorizing over 
experience is (...) fundamentally motivated and justified by conditions of efficacy and utility in serving our various aims and needs" 52 (let's say that the practical and instrumentalism are here germane). To put things in a nutshell, and even if some points of this last definition should be qualified, Wiener's approach certainly incorporates more of the "cosmology" or the broader empiricism of pragmatism, Thayer more of the epistemology, and of the idea that, as James and Dewey have it, the "knower" is an actor and not only a "spectator" and that the gist of the movement lies in a methodological attitude.

The point in recalling these two views of pragmatism is to see that, beyond the crude opposition between the "two" pragmatisms referred to in the first section (which in our eyes covers only the most superficial aspect of the problem and is not relevant to address the situation of Shusterman's pragmatism), there is another ongoing debate over whether pragmatism involves substantial theses - as in Wiener's account- or is merely a methodological strategy, compatible with many rival ontologies and approaches to experience - as evidenced in Thayer's account. Even admitting both approaches, there remains a debate over where the center of gravity lies.

As I mentioned at the outset, James officially endorsed the second opinion, that pragmatism was analogous to a "corridor" leading to a multitude of different "rooms" in a hotel, empiricists, absolutists, religious; to his eyes, the pragmatic method was compatible with many philosophical views ("To avoid one misunderstanding at least, let me say that there is no logical connexion between pragmatism, as I understand it, and a doctrine which I have recently set forth as 'radical empiricism! The latter stands on its own feet. One may entirely reject it and still be a pragmatist.53") But his whole practice objected to this rule: all the pragmatic clarifications in Pragmatism involve in their descriptions important tenets of radical empiricism.

It seems clear that Shustermanian Pragmatism is not only a "principle of method of right thinking" to use Peirce's phrase but involves substantive theses. To recall only the essential, the fundamentals of his pragmatism, as developed in "What Pragmatism means to me", certainly entail substantive theses about reality and agency, such as: (1") the changing nature of reality, (2") the purposive character of human action and mind, (3") a non-reductive naturalism, (4") anti- Cartesianism, (5") an emphasis on community, (6") an empiricist stance, ( 7 ") the future-looking dimension of concepts and products of mind, (8") Meliorism, (9") Holism, (10") Pluralism.

On a first reading, it is consonant with the larger picture I sketched in the last section where we saw that experience was a non-negotiable part of Shusterman's Pragmatism, which thus involves substantial commitments. To claim that Shusterman's list here simply takes earlier accounts of substantive pragmatism further would certainly be misleading, for at least two sets of reasons.

First, to take just one example, Shusterman's emphasis on the changing nature of reality (1"), is not exactly Wiener's (2) and (4): it is for Shusterman also the ground for human action and fallibilism. Each of the ten principles has 
consequences on the way philosophy can be lived: in a way, they are as much theoretical principles as practical maxims. The ten-point list might convey the impression that Pragmatism is the sum of all these characteristics, whereas its main lesson, according to Shusterman, is certainly reflexive; it should be applied to philosophy itself. If Pragmatism is the philosophy according to which every (theoretical) difference must make a possible difference in practice, then what kind of difference should be produced by the fact of endorsing a pragmatist philosophy? This difference should be read, according to Shusterman, not just in the way we write texts, but in the way we live:

If philosophy aims to make a difference in our lives, then why not practice it as an art of living, as most ancient philosophers recommended and several modern greats (such as Wittgenstein, James, Dewey, and Foucault) have likewise affirmed? Here philosophy's cultural politics could take the eminently pragmatic form of seeking to benefit life not merely by writing texts but by other forms of concrete praxis in the world, by more robustly embodied forms of action and cultivation, including somatic disciplines that can make a positive difference to the perception, performance, and attitudes of the practitioner and to her capacities to understand and productively engage with the people and environments that surround her.54

The eighth point (8"), related to meliorism, is not "another point"; it is in point of fact the perspective from which all the other points can be re-situated.

Second, Shusterman's writings give all these points a distinctive "feel" in the context of his attention to the soma. If each "principle" points, in its explanation, to a somatic dimension (habit, disposition, purpose, conduct), a naive reader might miss the measure in which this is central here or think that it is only captured in (3"), whereas in the tradition that Shusterman criticizes nearly all the ten principles have been so many ways to miss the centrality of the somatic perspective. (Shusterman 2008) gives reasons to think that the pragmatists, James and Dewey at least, have seen its importance55. If James's radical empiricism, Dewey's view of the common construction of good, Peirce's phenomenology and epistemology are the territories where their pragmatisms become concrete or "palpable", the same could be said about the soma as a dimension where the main philosophical problems are at home. Somaesthetics, as a project and now with its own achievements in TTTB, is the embodiment of Shusterman's meliorative pragmatism: "Briefly defined as the critical meliorative study of the experience and use of one's body as a locus of sensoryaesthetic appreciation (aesthesis) and creative self-fashioning, somaesthetics is therefore also concerned with the critical examination of the values, forms of knowledge, and disciplines of practice that structure such somatic experience or could improve it."56 
What about the pragmatic method? Here again, someone who just looks at the titles might think that what we said about his method - Shusterman's General Pragmatism - in section 1 largely echoes Thayer or even Peirce. Thayer's (1') concerns the semantic level and answers the question: in which way reference to practice, to practical bearings, can make our concepts or terms clear? In Peirce, this very question was encapsulated in the pragmatist maxim: "Consider what effects, which might conceivably have practical bearings, we conceive the object of our conception to have. Then, our conception of those effects is the whole of our conception of the object"57. There is an important difference, though, between Shusterman, on the one hand, and Thayer and Peirce, on the other hand. The pragmatist maxim, from Shusterman's perspective and in particular in all the texts published after Pragmatist Aesthetics might work, if strictly applied, in favor of a "conservative" approach to practices and meanings (or in favor of a kind of acquiescence to a given dispensation of our culture). But Shusterman's clarifications, on the contrary, typically relate the "established" meanings to possible transformations or variations of our experience, these transformations being not confined to pure word-plays, but deeply entrenched in practices. So, if his philosophy makes room for Thayer's three criteria, (1'), the explication of meanings, is then strictly submitted to (2') and (3'); the semantic perspective is definitely secondary to the meliorist perspective:

Though beginning with a recognition of the established meanings and limits of the concepts it treats, the pragmatist examines whether a concept's range can be usefully extended (or narrowed) in places where its borders seem vague and flexible enough to allow such extension (or restriction) without destroying the concept's principal meaning and value but rather making it more meaningful and useful in improving our aesthetic understanding and experience. 58

This is certainly more a Jamesian kind of pragmatism than a Peircian one; the significance of a concept is not revealed in a line of conduct or in general modes of rational conduct, but in its bearing upon the conduct of life. Shusterman's pragmatist maxim is thus not (only) a rule to make extant meanings clearer, it is a rule to extend them; it takes "meaning" not only in the classical and semantical sense, but also in the existential one (hence his title: What Pragmatism means to me). Explaining what $X$ means to me is not only try and explain its contents to my fellow men, it is also telling why we should care for it. This understanding of the pragmatist rule is fully part of a perfectionist vision.

\section{Perfectionism in practice}

The core of Chapter 8 of TTTB deals with just that question, insofar as it defends a vision of pragmatism and somaesthetics as a variant of "cultural politics" against "a powerful rival philosophy of culture that denies the value, and 
indeed the philosophical sense, of somaesthetics"(TTTB, 167), Rorty's own position, at least before Philosophy as Cultural Politics. The chapter is meant both as an homage and critique, but it is certainly Shusterman's sharpest critique of Rorty, not only of key points in his philosophical theories, but also of his incomplete or inconsistentperfectionism.

I have already addressed Shusterman's defense of experience against charges of succumbing to the myth of the given, but section III of chapter 8 drives his argument further. Rorty's "textualism" would be guilty of endorsing an essentialist and a metaphysical account of reality. His condemnation of experience would itself be built on what is ultimately "an essentialist view of nature as essentially linguistic" (TTTB, 175) and Rorty's "insistence that reality is thoroughly and essentially contingent might itself be construed as a metaphysical view" (Ibid., 177). This last insistence would be devastating for the possibility of perfectionism since it can lead to downplay those "stubborn persistent realities that are often expressed in powerful social norms" (Ibid.) Rorty would thus not only be inconsistent with his own anti-metaphysical stance, he would also undermine the very intelligibility of perfectionism since challenging a current dispensation of our culture always has to face powerful and persistent forces that discourage these kind of inquiries. Rorty's distinction between the public and the private would be at odds with the most central pragmatist positions: "Rorty fails to appreciate how pervasively the public, social, and economic fields (through our shared public language, social norms and advertised ideas of fulfillment) shape what he advocates as the individual's original, private visions of self-perfection".

This is a double-barreled argument, against Rorty's approach to irony, but also certainly against Shusterman's own opponents, when they don't see that somaesthetics involves a stance on all the public and social dimensions of the soma. Lastly, Rorty's opposition between "cultural politics", as practiced by the elites in the academe, involving racial, gay, feminist and other identity politics, and "real politics", involving mainly "the balance of power between the rich and the poor"(as quoted p. 179) would be irresponsible: one could not make sense of the fact that these cultural issues connect with real politics; or, as Shusterman puts it, it is "dangerously simplistic (though typically neoliberal) for Rorty to portray political suffering and injustice in narrowly economic terms of rich and poor"(179). What, then. can be saved of Rorty for Shusterman's project? A shallow reading of chapter 8 might convey the impression that, despite these disagreements, there was some common ground between Rorty's final positions and Shusterman's perfectionism. However, I think that Shusterman's inventory of the reasons why Rorty could or should have embraced somaesthetics but finally did not, should be read as still more radical criticisms.

Of course, on the face of it, reading the history of philosophy as a "series of efforts to modify people's sense of who they are, what matters to them" or as "making a difference to the way human beings live" sounds like a basic perfectionist claim, perfectly consonant with the way Shusterman has described philosophy as a way of life. But the way Rorty has pursued this goal, by writing texts and as an individualistic project, is at odds with the idea that philosophy can change life "not merely by writing texts but by other forms of praxis in the 
world", including somatic disciplines. Shusterman's reading, here, clearly echoes the one he had given of Cavell (and also Rorty) in Practicing Philosophy.

The point is worth mentioning, since Cavell's views are highly influential in the debate over perfectionism, and these views repeatedly exclude such projects as James's, Dewey's and implicitly Shusterman's59. Stanley Cavell has been, and still is, a staunch advocate of (Emersonian) perfectionism. His Harvard lectures, published in 2004 under the title Cities of words. Pedagogical Letters on a Register of Moral Life 60 , are a full-scale survey of the tradition of moral perfectionism, as Cavell sees it, borrowing as much from the philosophical tradition as from Hollywood comedies and melodramas. Cavell's philosophical heroes - in addition to Wittgenstein and Austin, who are also featured in Shusterman's pantheon - are Emerson, Locke, Stuart Mill, Kant, and Nietzsche. Cavell opposes the perfectionist stance to "deontological" attitudes (in which a principle or rule determines what is right in a line of conduct), and to "utilitarianism" (whose emphasis is on the consequences, individual or social, that we expect from a line of conduct). Perfectionism for Cavell would focus on our attempts to reach our "unattained but attainable self", and he often adds that the privileged way to reach it is through conversations where we try and make ourselves intelligible to ourselves and to others, a non-trivial task indeed. If it does not come as a surprise that Emerson is a pivotal figure in such an approach, this last line of thought is so central to Shusterman's writings, from Pragmatist Aesthetics and into the present, that it is always perplexing to find that pragmatist perfectionism is nearly absent - whether of James, of Dewey or of Shusterman - from Cavell's accounts 61 .

As already mentioned, Shusterman has developed his own interpretation of Cavell's position in Practicing Philosophy, where Cavell is portrayed as somehow trapped in a more subtle form of textualism than Rorty's. Since the most genuine Cavellian act of self-assertion would still be the writing of a text, actual praxis would remain at the margins. "By emphasizing philosophy as writing and reading, while saying nothing about other forms of self-perfection, Cavell does not do enough to prevent philosophy's reappropriation as a merely textual activity." 62 Cities of words is a case in point for Shusterman, since its title might be read as an indication that Cavell does not reach "beyond the ideal 'city of words' and idealistic dimensions of self-transformation." 63 But we should note that some of Cavell's heroes in that book are less likely to be trapped in this textualist approach, at least for Locke, Kant, and Mill. Cavell's stress on the importance of conversation certainly involves aspects that are not confined to a merely textual self-perfection. Conversely, perhaps pragmatist meliorism is virtually absent from Cavell's account because he finally entertains the same vision of pragmatism and practice as most analytic philosophers. Cavell persistently sees pragmatism as a kind of narrow instrumentalism, so that enrolling Emerson in the pragmatist tradition would be a severe mutilation of the transcendentalist approach 64 . Defending the credentials of perfectionist pragmatism will thus certainly involve at some stage a debunking of such a narrowly instrumentalist 
reading of the pragmatist tradition. This task remains to be achieved.65. Still, if Rorty is charged with the same kind of one-sided, textual perfectionism, his reluctance to admit somatic disciplines as a means to advance the cultivation of sentiment he sees as a moral progress cannot be construed here as a form of resistance to the pragmatist stance. Rorty seems not only one-sided but even inconsistent in his opposition to somaesthetics, precisely where a perfectionist pragmatism is at stake.

Shusterman thus occupies a singular position in the present philosophical debate: He must defend the claims of experience against upholders of different forms of linguistic pragmatism, and defending these claims involves developing an account of experience where the latter is not grasped from the standpoint of epistemology - as a possible foundation - but is understood as lived experience, as capable of enhancement. This, in turn, leads him to defend the claims of pragmatism, of his own melioristic pragmatism, against influential moral perfectionists. To do so, he introduces the positive interdisciplinary project of somaesthetics, building on a blind spot common to both of the philosophical camps he counters and in which the somatic perspective is systematically overlooked. This brings us to a last objection that is sometimes raised by both camps (and by other critics of somaesthetics). The stress on somatic disciplines has sometimes been interpreted by distracted readers as implying a kind of extreme individualism or at least a renouncing of social change and cultural criticism which would turn perfectionism into a purely private practice. A sure indication that such criticism is mistaken is that the resistance to this kind of empiricism and perfectionism has historical precedents that are social and political rather than merely theoretical. More than a century ago, Mill proposed his own explanation of the "natural hostility" faced by empiricists, especially when they address what seems to be the most private part of the subject's life, namely one's feelings; and this explanation still seems relevant:

The practical reformer has continually to demand that changes be made in things which are supported by powerful and widely-spread feelings, or to question the apparent necessity and indefeasibleness of established facts; and it is often an indispensable part of his argument to show, how those powerful feelings had their origin, and how those facts came to seem necessary and indefeasible. 66

Feelings and facts are neither necessary nor indefeasible, and the first step in their reform - which is a precondition of social change - lies certainly, beyond the historical explanation of their genesis, precisely in the pragmatic and practical parts of somaesthetics which Shusterman proposed as a "critical meliorative study of the experience and use of one's body as a locus of sensoryaesthetic appreciation and creative self-fashioning" and that also involves praxis and somatic discipline. This is perfectionism brought back to where it belongs, in 
enhanced experience. Perfectionism in practice at last.

Works cited

Boydston, Jo Ann, Patricia Baysinger, Barbara Levine, and Sidney Hook. 1981. "John Dewey: The Later Works, 1925-1953, I: 1925; With a New Introd. by John Dewey, Ed. by Joseph Ratner." Carbondale: Southern Illinois UP 437.

Brandom, Robert. 1994. Making It Explicit: Reasoning, Representing, and Discursive Commitment. (Cambridge: Harvard University Press).

Brandom, Robert. 2000. Articulating Reasons: an Introduction to Inferentialism. (Cambridge, Mass.: Harvard University Press).

Brandom, Robert. 2002. "When Philosophy Paints Its Blue on Gray: Irony and the Pragmatist Enlightenment." Boundary 29 (2):1-28.

Brandom, Robert B. 2004. "The Pragmatist Enlightenment (and its Problematic Semantics)." European Journal of Philosophy 12 (1):1--16.

Cavell, Stanley. 1998. "What's the Use of Calling Emerson a Pragmatist?" In The Revival of Pragmatism, edited by M. Dickstein, 72-80. (Durham: Duke University Press). Press).

Cavell, Stanley. 2004. Cities of Words. (Cambridge: Harvard University

Dewey, John, and Jo Ann Boydston. 1981. The later works, 1925-1953. (Carbondale; London: Southern Illinois University Press ; Feffer \& Simons).

Dickstein, Morris. 1998. The revival of pragmatism : new essays on social thought, law, and culture. (Durham ; London: Duke University Press).

Festenstein, Matthew, and Simon Thompson. 2001. Richard Rorty : critical dialogues. (Cambridge, UK ; Malden, MA: Polity Press).

Girel, Mathias. 2004. "Les angles de l'acte. Usages d'Emerson dans la philosophie de William James." Cahiers Charles V 37, octobre:207-245.

Girel, Mathias. 2014. "L'expérience comme verbe." Education permanente 198 (1):23-34.

Haack, Susan. 1996. "As for that Phrase "Studying in a Literary Spirit..."." Proceedings and Addresses of the American Philosophical Association 70 (2):5775 .

James, William. 1978. Essays in Philosophy, The works of William James. (Cambridge, Mass.: Harvard University Press). 
James, William, Fredson Bowers, and Ignas K. Skrupskelis. 1978.

Pragmatism, a new name for some old ways of thinking ; The meaning of truth, a sequel to Pragmatism. (Cambridge, Mass.: Harvard University Press).

James, William, and Bruce Kuklick. 1988. Writings, 1902-1910. (New York, N.Y.: Literary Classics of the United States: Distributed to the trade in the U.S. and Canada by Viking).

Koskinen, Heikki J., and Sami Pihlström. 2006. "Quine and Pragmatism " Transactions of the Charles S. Peirce Society: A Quarterly Journal in American Philosophy 42 (3):309-346.

Lavergne, C. , and T. Mondémé. 2008. "Le corps pragmatiste. Entretien avec Richard Shusterman (Interview with Richard Shusterman)." Tracés:255-267.

Lovejoy, Arthur Oncken. 1963. The Thirteen Pragmatisms, and Other Essays. (London: Oxford Univ Pr).

Margolis, Joseph. 2002. Reinventing Pragmatism, American Philosophy at the End of the XXth Century. (Ithaca, Londres: Cornell University Press).

Menand, Louis. 2001. The Metaphysical Club. (New York: Farrar Straus \& Giroux).

Mill, John Stuart. 1874. Autobiography. (London: Longmans).

Mounce, H. O. 1997. The Two Pragmatisms: From Peirce to Rorty. (New York: Routledge).

Mumford, Lewis. 1926. The golden day; a study in American experience and culture. (New York,: Boni and Liveright).

Murphy, John P. 1990. Pragmatism: From Peirce to Davidson. (Boulder: Westview Press).

Peirce, Charles S., Max Harold Fisch, and Christian J. W. Klossel. 1982Writings of Charles S. Peirce : a chronological edition. (Bloomington: Indiana University Press).

Quine, W. V. 1981. "The Pragmatists Place in Empiricism." In Pragmatism Its Sources and Prospects, edited by Philip M Zeltner, 21-39. (Columbia: Univ of S Carolina Pr).

Rorty, Richard. 1967. The Linguistic turn: Essays in philosophical method with two retrospective essays. (Chicago: University of Chicago Press).

Rorty, Richard. 1979. Philosophy and the mirror of nature. (Princeton: Princeton University Press).

Rorty, Richard. 1982. Consequences of pragmatism: Essays, 1972-1980.

Translated by J-P. Cometti, Conséquences du pragmatisme, Paris, Le seuil, 1993. (Minneapolis: University of Minnesota Press).

Saito, Naoko. 2005. The Gleam of Light. Moral Perfectionism and Education in Dewey and Emerson. (New York: Fordham University Press). 
Shusterman, Richard. 1978. "The Logic of Interpretation." Philosophical Quarterly 28 (113):310-324.

Shusterman, Richard. 1984. The object of literary criticism, Elementa : Schriften zur Philosophie und ihrer Problemgeschichte. (Würzburg, Amsterdam: Königshausen \& Neumann ; Rodopi).

Shusterman, Richard. 1988a. "Croce on Interpretation: Deconstruction and Pragmatism." New Literary History 20 (1): 199-216.

Shusterman, Richard. 1988b. T S Eliot and the Philosophy of Criticism. (Ny: Columbia Univ Pr).

Shusterman, Richard, ed. 1989a. Analytic aesthetics. (Oxford, UK ; New York, NY, USA: B. Blackwell).

Shusterman, Richard. 1989b. "Eliot's Pragmatist Philosophy of Practical Wisdom." The Review of English Studies 40 (157): 72-92.

Shusterman, Richard. 1989c. "Why Dewey Now?" Journal of Aesthetic Education 23 (3):60-67.

Shusterman, Richard. 1992. L'art à l'état vif. (Paris: Minuit).

Shusterman, Richard. 1994a. "Dewey on Experience: Foundation or

Reconstruction?" Philosophical Forum 26 (2):127-148.

Shusterman, Richard. 1994b. "Eliot as philosopher." In The Cambridge companion to TS Eliot, edited by A. David Moody, 31-47. (Cambridge: Cambridge University Press).

Shusterman, Richard. 1997a. Practicing Philosophy: Pragmatism and the Philosophical Life. (New York: Routledge).

Shusterman, Richard. 1997b. "Putnam and Cavell on the Ethics of Democracy." Political Theory 25 (2):193-214.

Shusterman, Richard. 1999. "Emerson's Pragmatist Aesthetics." Revue Internationale de Philosophie 53 (207):87-99.

Shusterman, Richard. 2002. "Regarding Oneself and Seeing Double: Fragments of Autobiography." In The Philosophical I: Personal Reflections on Life in Philosophy, edited by George Yancey, 1-21. (Lanham: Rowman and Littlefield).

Shusterman, Richard. 2008. Body Consciousness: A Philosophy of Mindfulness and Somaesthetics: Cambridge University Press).

Shusterman, Richard. 2009a. L'objet de la Critique littéraire. (Paris: Questions théoriques).

Shusterman, Richard. 2009b. "Lard de la critique, Entretien avec Eric Loret, May, 28 2009." Libération, 5/28/o9.

Shusterman, Richard. 2009c. "Somaesthetics and C. S. Peirce." Journal of Speculative Philosophy 23 (1):pp. 8-27. 
Shusterman, Richard. 2010a. "Pragmatism and Cultural Politics: From Rortian Textualism to Somaesthetics." New Literary History 41 (1):69-94.

Shusterman, Richard. 2010b. "What Pragmatism means to me: Ten Principles." Revue Française d'études américaines 124:59-65.

Shusterman, Richard. 2012. "A Pragmatist Path through the Play of Limits: from Literature to Somaesthetics." In Shusterman's Pragmatism: Between Literature and Somaesthetics, edited by Dorota Koczanowicz and Wojciech Małecki. (Amsterdam, New York: Rodopi).

Thayer, H. S. 1981. Meaning and action : a critical history of pragmatism. $2 \mathrm{~d}$ ed. (Indianapolis: Hackett Pub. Co.).

Väkevä, L. 2002. "Interviewing richard shusterman: Part i." Action, Criticism, and Theory for Music Education 1 (1):np.

Wiener, Philip. 1949. Evolution and the Founders of Pragmatism. (Cambridge: Harvard Univ Pr).

Wiener, Philip. 1973. "Art. " Pragmatism »." In Dictionary of the History of Ideas, edited by Philip Wiener, 551-570. (New York: Charles Scribner's sons).

Acknowledgments: A first version of this paper was published in Chinese, in World philosophy (China), 6, october 2011, "Lun Shusiteman zai dangqian shiyongzhuyi zhong de diwei"(拓展经验: 论舒斯特曼在当前实用主义中的地位), p. 45-6o (Tr by Wang Hui).

\section{Notes}

1 (James 1978, 146).

2 Think of it if you wish as an architectural project, TTTB, Ch. 10.

3 A caveat, maybe: it is not my aim here to reduce an ever-growing and multifaceted bibliography of more than 200 papers to a single stance, the following should be read as one of the paths what can use, when orienting oneself in Richard Shusterman's works.

4 (Rorty 1979). 
5 Rorty (1982).

6 See the volume: (Dickstein 1998).

7 (Rorty 1967)

8 A cogent criticism of this notion of a revival can be found in (Margolis 2002, 2). Margolis thinks that assuming that there is a pragmatist revival causes a "conceptual embarrassment" since "Pragmatism never had a single doctrinal or even methodological center". He further claims that the so-called revival is a convenient term used in a context of "selfadvertisement": "Had not Rorty and Putnam identified themselves as pragmatists in the process of reviewing and disputing the professional prospects of realism, relativism, knowledge under the condition of history, public and private responsibility and values, no one would have envisaged a "revival." It is a genuine revival for all that, and it is succeeding largely because of that single contingency. Putnam and Rorty literally tell us how to read the pragmatists in order to count themselves as their closest progeny."(Ibid., 3).

9 (Murphy 1990), (Mounce 1997).

10 Which does not mean that he is alone on that part of the field, see for example (Haack 1996). Assessing exactly where a philosopher like Ian Hacking lies is a trickier question.

11 On the idea of "wrapper-definition", as definition that covers all the extension of a notion and preserves the content from contacts with the environment (and thus fulfills a "conservative" function), see (Shusterman 2012).

12 See (Brandom 2000).

13 (Brandom 2002).

14 (Quine 1981) is more a reflection on empiricism than on pragmatism strictly speaking. On Quine's ambiguous relationship to pragmatism, see (Koskinen and Pihlström 2006).

15 (Rorty 1982, xviii). 
16 For an account of the sterility of this Auseinandersetzung, see again (Margolis 2002).

17 Crossing the borders is a familiar experience with Shusterman: "Like it or not (and initially I greatly disliked it), my image had evolved from a mainstream, Oxfordtrained analytic aesthetician into a limit-defying provocateur, who had to be kept at some distance from the inner circles of power within the mainstream aesthetics establishment however much it still accorded my work a respectful hearing." (Shusterman 2012).

18 (Rorty 1982, xviii)

19 See for example, for this vein, (Shusterman 1978). His thesis, later published as (Shusterman 1984), was supervised by Urmson and Stuart Hampshire was in the committee. Urmson was the literary coexecutor of J. L. Austin.

20 (Shusterman 1984).

21 (Shusterman 1988b). See also (Shusterman 1994b), on the relationship between Aristotle's phronesis and Eliot's pragmatism (the title of (Shusterman 1989b) was still more explicit). This continuity argument is a reading Shusterman endorses in the preface to the french translation of (Shusterman 1984). Which does not mean that the main tenets of his subsequent work on Pragmatist Aesthetics and his reinterpretation of Dewey would already be in this early work.

22 See for example (Shusterman 1992, 13).

23 (Shusterman 1989a). A paper on Croce also endorses a pragmatist, as opposed to Romantic, strategy in interpretation: "On the other hand, the pragmatist interpretation requires no perfect "foundational" objectivity of historical research and

no titanic leap of imagination to place us in the mind of the author. For both the author qua author and the intuition or meaning of his work are seen not as "real" objects already fully and finally determined in the past, but rather as entities continuously shaped and reshaped by literary historical understanding. This understanding is essentially imaginative and creative, molding facts rather than mirroring them."(Shusterman 1988a, 210) But the main pragmatist reference in the paper is still Rorty. 
24 (Shusterman 1989a, 15).

25 J. Dewey, Experience and Nature : (Boydston et al. 1981, 298).

26 Since the notion of analytic acquiescence plays a prominent role in Shusterman's text, it is worth keeping in mind that there is a famous text by (Mumford 1926), which derides the "pragmatic acquiescence". See Dewey's rebuttal, LW3, 45-51.

27 (Shusterman 1989a, 15).

28 (Shusterman 2009b). See also the preface to (Shusterman 2009a).

29 (Shusterman 1989c, 66).

30 See (Shusterman 2002) and, more detailed on the question of pragmatism, (Shusterman 2012). An interview in French gives some details about the importance of dance in this reorientation (Lavergne and Mondémé 2008, 256-57).

31 (Dewey and Boydston 1981, vol. 10, 10-12).

32 (Shusterman 1994a, 148).

33 Shusterman in (Väkevä 2002, 4).

34 "Some good books have been written about painting, others about literature, others about music, others about sex, and still others about birdwatching. But I have never read a book that succeeded in saying something interesting about what all these have in common. What Shusterman calls 'the somatic' typically turns up in all these books, in one form or another. But I am not sure that we need a 'somatic aesthetics' because I am not sure that we need an aesthetic theory, or an aesthetic programme, at all." Rorty, in (Festenstein and Thompson 2001, 156).

35 (James and Kuklick 1988, 783).

36 Ibid. 
37 Ibid., 803. See the chapter on James in (Shusterman 2008).

38 (Brandom 1994).

39 (Brandom 2000, 205-206, n.7).

40 Ibid.

41 (Brandom 2004, 15)

42 (Shusterman 1994a), retrieved in (Shusterman 1997a).

43 (Shusterman 1997a, 157).

44 (Shusterman 1997a, 170).

45 See (Girel 2014).

46 (Shusterman 2012); see also (Shusterman 2010a).

47 See Shusterman, "A Philosopher in Darkness and in Light. Practical Somaesthetics and Photographic Art,” Lucidity. Inward Views : Le Mois de la Photo à Montréal 2011. Anne-Marie Ninacs (ed.) Montreal : Le Mois de la Photo à Montréal, 2011.

48 (Shusterman 2010b).

49 (Lovejoy 1963).

50 (Wiener 1973, 553).

51 A spirit well captured in (Wiener 1949) but a very entertaining account is given in the chapter "Brazil" of (Menand 2001).

52 (Thayer 1981, 431). 
53 (James, Bowers, and Skrupskelis 1978, Preface).

54 (Shusterman 2010a, 82-83).

55 For Peirce, see (Shusterman 2009c).

56 (Shusterman 2010a, 80).

57 (Peirce, Fisch, and Klossel 1982-, vol.3, 266 ).

58 (Shusterman 2012).

59 I have dealt with Cavell, Emerson and James, from the standpoint of a theory of the Act elsewhere, see (Girel 2004).

60 (Cavell 2004).

61 See in particular R. Shusterman, La philosophie comme vie éveillée chez Emerson et Thoreau, Cahiers philosophiques, $\mathrm{n}^{\circ}$ 120, décembre 2009.

62 (Shusterman 1997b, 210), retrieved in (Shusterman 1997a).

63 (Shusterman 1997b, 210). The phrase "city of words" is used by Socrates in Plato's Republic.

64 That's the gist of his criticism in (Cavell 1998).

65 See nevertheless, for some continuities between Emerson and Dewey, (Saito 2005). See (Shusterman 1999).

66 (Mill 1874). 